\title{
Hp and pH: Implications for the eradication of Helicobacter pylori
}

\author{
RICHARI) H HUNT, FRCP, FRCP(EIDN), FRCPC, FACG
}

\begin{abstract}
RH HUNT. Hp and $\mathrm{pH}$ : Implications for the eradication of Helicobacter pylori. Can J Gastroenterol 1993;7(5):406-410. Helicobacter pylori infection causes inflammation of the gastric and duodenal mucosae, which results in a disturbance of the regulatory mechanisms for gastrin, gastric acid and pepsin secretion. Acid secretion may be decreased, normal or increased, depending on the stage of infection, although the meal-stimulated gastrin response is invariably elevated. The exact mechanisms involved are not known but may be due to the release of cytokines in response to bacterial toxins. H pylori colonization is reduced by effective acid suppression with proton pump inhibitors, although it is not eradicated. In combination with amoxycillin, omeprazole, up to $40 \mathrm{mg}$ twice daily, eradicated the organism in up to $82 \%$ of cases. This synergistic effect may be due to a direct effect of omeprazole on the organism, the protection of amoxycillin from acid degradation, or enhancement of host defence mechanisms accompanying acid suppression.
\end{abstract}

Key Words: Amoxycillin, Duodenal ulcer, Eradication, Gastric acid, Helicobacter pylori, Omeprazole, $\mathrm{pH}$

\section{«Hp» et $\mathrm{pH}$ : implications pour l'éradication de Helicobacter pylori}

RÉSUMÉ: L'infection à Helicobacter pylori provoque une inflammation des muqueuses gastriques et duodénales, qui résulte en une altération des mécanismes régulateurs de la sécrétion de gastrine, d'acide gastrique et de pepsine. La sécrétion acide peut être diminuée, normale ou accrue, selon le stade de l'infection, bien que la réponse de la gastrine stimulée par la prise d'aliments soit invariablement élevée. Les mécanismes précis en jeu sont inconnus, mais pourraient être attribuables à la libération de cytokines en réponse à des toxines bactériennes. La colonisation de H pylori est réduite par une suppression efficace de l'acide à l'aide d'inhibiteurs de la pompe à protons, bien que l'éradication ne soit pas obtenue ainsi. En association avec l'amoxycilline, l'oméprazole, jusqu'à concurrence de $40 \mathrm{mg}$ deux fois par jour, a enrayé le pathogène chez $82 \%$ des cas. Cet effet synergique peut être dû à une action directe de l'oméprazole sur le pathogène, à une protection de l'amoxycilline contre la dégradation par l'acide ou à l'amélioration des défenses de l'hôte qui accompagne la suppression de l'acidité.

Division of Gastroenterology, McMaster University Medical Centre, Hamilton, Ontario

Correspondence: Dr Richard Hunt, 4W8E Health Sciences Centre, McMaster University Medical Centre, 1200 Main Street West, Hamilton, Ontario L8N 325. Telephone (416) 521-2100 ext 6404. Fax (416) $521-5072$

This article is reprinted from: $\mathrm{Hp}$ and $\mathrm{pH}$ : Implications for the eradication of Helicobacter pylori, by RH Hunt, from Scandinavian Journal of Gastroenterology 1993:28(Suppl 196):12-5, by permission of Scandinavian University Press
$\mathrm{D}$ UODENAL ULCER HAS TRADITION. ally been considered an acid-related disease, which responds readily to pharmacological or surgical reduction of acid secretion, and a considerable change in thought is required to accept the concept that ulceration in the duodenal cap might be the result of infection with Helicobacter pylori. Colonization with $H$ pylori leads to a sequence of pathophysiological events that include mucosal inflammation, weakening of the mucus bicarbonate barrier, superficial epithelial cell damage, increased serum gastrin levels with defective feedback control, a possible increase in parietal cell mass, and the development of gastric metaplasia in the duodenal cap.

These observations have led to the concept of a complicated interplay between the organism and the host, whereby the sophisticated and highly integrated normal mucosal defence mechanisms are compromised in the presence of normal or elevated levels of acid and, perhaps, pepsin secretion. Ulceration may then occur as a result of this imbalance.

\section{RELATIVE ROLES OF ACID AND H PYLORI IN ULCER DISEASE}

$H$ pylori colonizes the antrum of the stomach with the aid of its urease mechanism and motility generated by spiral structure and multiple flagella. Urease, together with a spectrum of bacterial products, leads to weakening 
of the mucus/bicarbonate layer and damage to the surface epithelial cells. The release of cytokines with an inflammatory response results in further damage to mucosal cells and may affect the regulatory mechanisms involving gastric secretion and motility. These changes may lead, over time, to an increase in the parietal cell mass and hypersecretion of gastric acid, with the subsequent development of gastric metaplasia in the duodenal cap. These areas of gastric metaplasia then become colonized with $\mathrm{H}$ pylori from the gastric antrum, leading to further inflammation in the duodenal cap.

Inflamed gastric metaplasia in the duodenal cap, with altered sialomucin production, and the already compromised junctional mucosa, weakens the normally well-orchestrated and buttressed mucosal defences. With ongoing normal or increased acid secretion and peptic activity, mucosal damage and ulceration occur.

\section{H PYLORI AND INTRAGASTRIC ACIDITY}

$H$ pylori does not thrive in a hypoacidic environment. The organism colonizes at the interface of the mucus/bicarbonate layer and surface epithelial cells, where the $\mathrm{pH}$ is between 6 and 7 . In vitro studies show that the organism will replicate in the presence of urea down to a $\mathrm{pH}$ of 4.3 , and it will survive without replication down to a pH of 2.3. When acid secretion is effectively suppressed, the minimal $\mathrm{H}^{+}$in the lumen of the stomach results in little or no back diffusion of acid across the mucus/bicarbonate layer. The $\mathrm{pH}$ of the submucus environment then rises because of ongoing urease activity and becomes alkaline due to unbuffered ammonia. It seems probable that $H p y-$ lori can tolerate this alkaline $\mathrm{pH}$ for only a short period of time.

\section{H PYLORI AND GASTRIC ACID SECRETION}

Reduced secretion: $H$ pyleni may be associated with hyposecretion, hypersecretion or normal secretion of gastric acid, and this may be determined by the stage of infection. The term 'hypochlorhydric gastritis' was first coined by
Osler in 1905 (1), who described an acute dyspeptic illness remarkably similar to that described by two volunteers who ingested $H$ pylori and other subjects involuntarily infected (2). In the selfinoculation studies, both volunteers became infected only after predosing with an $\mathrm{H}_{2}$ receptor antagonist, and in one well-documented case an acute gastrit is occurred with prolonged hypochlorhydria, as determined by the $\mathrm{pH}$ of basal acid samples (3).

Epidemic hypochlorhydria: The natural history of epidemic hypochlorhydria is not well known, but, from a review of the limited studies on this topic, it may last for weeks or months (2). Parietal cell function may be directly affected by H pylori or by mediators of the inflammatory response that accompanies the gastritis. In vitro, $H$ pylori inhibits acid secretion, as measured by ${ }^{14} \mathrm{C}$-aminopyrine in isolated guinea pig parietal cells (4) or rabbit gastric glands (5). In the presence of acute inflammation, several cyrokines are produced, including interleukin (IL)-1 $\beta$, and these may also reduce acid secretion $(6,7)$. It is presumed that the reduction in gastric acid secretion that sometimes accompanies acute infection with $H$ pylori somehow facilitates its colonization.

As gastritis extends proximally to involve the body and fundus, inflammation, which may or may not be accompanied by an autoimmune component, leads to the gradual atrophy of the parietal cell mass and reduction of acid secretory capacity.

Hypersecretion: The results of in vivo studies to determine the link hetween $H$ pylori and gastric acid secretion are unclear, due to the large number of retrospective studies, variability in study design, the mixed populations studied, and the different methods used both to detect the organism and to measure acid secretion (8). In summary, there appears to be no consistent effect on basal acid secretion, although there is a trend towards increased secretion in patients infected with $\mathrm{H}$ pylori. Two studies of pentagastrin-stimulated acid secretion have suggested that there may be an increase in acid output, hut both suffer from the problems alluded to above $(9,10)$.
The data on $24 \mathrm{~h} \mathrm{pH}$ profiles are also inconsistent with several studies showing no clear changes. However, Wagner et al (11) did show a significantly lower median $24 \mathrm{~h} \mathrm{pH}$ in patients with duodenal ulcer ( $H$ pylori-positive, $\mathrm{pH}$ 1.34; H pylori-negative, $\mathrm{pH}$ 1.32), compared with others with gastritis ( $H$ pylomi-positive, $\mathrm{pH} 1.58 ; \mathrm{H}$ pylorinegative, $\mathrm{pH} \mathrm{1.63)}$ and healthy volumteers ( $H$ pylori-negative, $\mathrm{pH} 1.66$ ), but the differences were independent of H pylori status. Our own study (unpublished data), although limited by small numbers, demonstrated that the median $24 \mathrm{~h} \mathrm{pH}$ in $\mathrm{H}$ pylori-positive dus. denal ulcer patients $(\mathrm{pH} 1.16 \pm 0.6)$ was lower than in $H$ pylori-positive gastritis patients $(\mathrm{pH} 1.5 \pm 0.68)$ and $H$ pylorinegative normal volunteers $(\mathrm{pH}$ $1.36 \pm 0.37$ ). Furthermore, the median $24 \mathrm{~h} \mathrm{pH}$ in duodenal ulcer patients after ulcer healing and eradication of $\mathrm{H} p y$ lori showed a trend towards increased acidity ( $\mathrm{pH} 0.94 \pm 0.18)$. This would he consistent with the hypothesis that the parietal cell mass or response to stimulation is increased in duodenal ulcer patients with $H$ pylomi, due to the trophic action of gastrin, and does not immediately return to normal.

\section{H PYLORI, ACID, GASTRIN AND INFLAMMATION}

Patients with duodenal ulcer tend to have a pattern of acid secretion that is either normal or increased, and the parietal cell mass may also be increased, contributing to this hypersecretion of acid. An increase in meal-stimulated gastrin release with a defective inhibition of acid was first demonstrated in duodenal ulcer patients by Walsh et al (12). More recently, this exaggerated and prolonged meal-stimulated gastrin release has been reported in patients infected with H pylori (13-15). Furthermore, this abnormality is reversed when the infection is eradicated $(10,13-16)$.

The relationship between $H$ pylori infection and gastrin release is complex (17). It has heen suggested that the exaggerated gastrin response is due to alkalinization of the antral mucosa, as a result of the production of ammonia by $\mathrm{H}$ pylori urease activity interfering with 
the acid feedback on gastrin release by the antral G-cells (18). However, Chitajallu et al (19) have recently shown that gastric alkalinization following eradication of $\mathrm{H}$ pylori did not cause basal gastrin values to rise to the levels observed when $\mathrm{H}$ pylori was present. Furthermore, a recent study with highdose antibiotics effectively cleared the antrum rapidly of $H$ pylori, but it took several days for the gastrin release to. return towards normal, suggesting that this mechanism is altered by inflammatory mediators rather than changes in $\mathrm{pH}$ occurring locally in the mucus/bicarbonate layer or at the epithelial cell surface (Graham, personal communication). There is some further evidence in support of this alternative hypothesis. Dogs that had been systemically immunized showed a significant increase in gastrin levels when challenged orally with specific human gammaglobulin, compared with immunized control dogs (20). Also, when isolated antral mucosal cells were incubated with IL-1, a significant dose-dependent increase in gastrin release was observed (21).

Not only are meal-stimulated gastrin levels elevated in $H$ pylori infection, but the area under the curve (AUC) for gastrin over the whole $24 \mathrm{~h}$ period is increased, raising the possibility of a continuous trophic effect of gastrin on the parietal cell mass. However, it remains speculative as to whether the increased meal-stimulated gastrin release and raised AUC for gastrin have a trophic effect on the parietal cell mass, leading to increased acid secretion. Studies to date have been indirect and have not confirmed this hypothesis (22). However, experimental designs have been suboptimal, and the studies have not had a sufficiently prolonged follow-up period to determine whether acid secretion falls after eradication.

There has been a suggestion that bacterially derived amines produced by $H$ pyloni and other bacteria might be important in stimulating gastrin release $(14,23)$. In support of this hypothesis, gastrin release is reduced dramatically in patients with pernicious anemia and achlorhydria when the stomach is lavaged at $\mathrm{pH}$ 7. Furthermore, when gas- tric juice from these patients is perfused in the stomachs of conscious rats, gastrin secretion is elevated.

In patients given the proton pump inhibitor SKF 96022, plasma was measured before and after eradication of $H$ pylori, and it was shown that levels of gastrin fell significantly (22). This supports the view that the hypergastrinemia found in association with $\mathrm{H}$ pylori is not due to an increase in antral mucosal $\mathrm{pH}$ caused by bacterial ammonia production, but by other products of bacterial metabolism or by mediators associated with the mucosal inflammation.

\section{H PYLORI, PEPSINOGEN AND PEPSIN SECRETION}

The pepsinogens are a group of proenzymes that are secreted by the chief cells and are converted to pepsins in the gastric lumen in the presence of acid. The pepsinogens are classified as two immunologically distinct subtypes, pepsinogens $\mathrm{A} / \mathrm{I}$ and $\mathrm{C} / \mathrm{II}$, which are detectable in the blood or serum. Before $H$ pylori was isolated, the serum pepsinogen profile was shown to be elevated in patients with ulcer disease (24), and in patients with chronic gastritis the pepsinogen profile correlates with the histological severity of the gastritis (25). Recently, it has been shown that eradication of H pylori is accompanied by a decrease in both pepsinogen $\mathrm{A}$ and $\mathrm{C}$ and a rise in the ratio of pepsinogen $\mathrm{A}: \mathrm{C}$.

\section{H PYLORI AND THE EFFECTS OF PROTON PUMP INHIBITION}

Omeprazole, 20 and $40 \mathrm{mg}$ daily, has suppressed $H$ pylori in some studies but not in others. The reasons for this are difficult to assess, but patient numbers have generally been small, the diagnosis and criteria of patients entered are heterogeneous, and biopsy sites in the stomach variable, thus confounding interpretation.

While treatment with omeprazole alone may suppress $\mathrm{H}$ pylori, the same is not found with the $\mathrm{H}_{2}$ receptor antagonists. It is unclear whether the effect results from the greater reduction in gastric acid secretion, or whether it is due to unique characteristics of ome- prazole or the proton pump inhibitors as a class.

Antral gastritis improves in patients taking omeprazole, and the bacteria are few at this site; they appear to migrate to the gastric lumen (26) or to the fundus, where the environment may be more acidic.

Omeprazole and lansoprazole have been investigated in vitro for their activity on $\mathrm{H}$ pylori $(27,28)$. The minimal inhibitory concentration for omeprazole is between 12.5 and $50 \mu \mathrm{g} / \mathrm{L}(27$. Goldie, Van Zanten and Hunt, unpub. lished data), and it appears to be increased by substitution of position 4 of the pyridine ring by a fluoro-alkoxy group (27). These studies have also suggested that acid-converted rearrangements of the parent compounds might be two to four times more potent than the parent compounds.

\section{RATIONALE FOR EFFECT OF OMEPRAZOLE COMBINED WITH AN ANTIBIOTIC ON H PYLORI}

Omeprazole, $20 \mathrm{mg}$ daily, provides effective inhibition of intragastric acidity, maintaining the $\mathrm{pH}$ above 3 for 16 to $18 \mathrm{~h} \mathrm{(29).} \mathrm{The} \mathrm{reduction} \mathrm{in} \mathrm{intralu-}$ minal $\mathrm{H}^{+}$activity will reduce the $\mathrm{pH}$ gradient across the mucus/bicarbonate layer, raising the $\mathrm{pH}$ at the surface of the epithelial cell-possibly to alkaline levels. This could explain the proximal migration of the organism to the acidsecreting fundus which is seen in patients taking omeprazole (26).

Many antibiotics are rapidly degraded by gastric juice, but amoxycillin monotherapy eradicates $H$ pylori in up to $25 \%$ of cases (30-32). Amoxycillin given intravenously does not appear in gastric juice under normal circumstances $(33,34)$, suggesting that amoxycillin may act topically in the stomach. The prolonged elevation of intragastric $\mathrm{pH}$ increases the concentration of acidlabile antibiotics in gastric juice and may also prolong their effectiveness.

It is possible that an elevated intragastric $\mathrm{pH}$ enhances the environment for the optimal effectiveness of the host defence mechanisms. The secretion of $H$ pylori-specific immunoglobulin has an indirect correlation with the degree of invasion by the organism (unpub. 
lished data). Under normal circumstances, immunoglobulin secreted into the stomach coats any luminal organisms. However, immunoglobulins are rapidly degraded by peptic activity and gastric juice at low $\mathrm{pH}$. Thus, the elevation of intragastric $\mathrm{pH}$ above 3 for prolonged periods might extend the half-life and effectiveness of secreted immunoglobulin. Little is known about the pH-dependence of other host responses to $H$ pylori. It is possible that the effective reduction in acidity seen with omeprazole, $40 \mathrm{mg}$ twice daily, optimizes the $\mathrm{pH}$ in the mucus bicarbonate layer for neutrophil function.

\section{RESULTS OF OMEPRAZOLE/ AMOXYCILLIN TRIALS}

The results of clinical trials with omeprazole and amoxycillin showed considerable discrepancy in eradication rates. The duration of treatment and dose regimens were very variable, and different criteria for eradication were applied. In most instances, the trials were not randomized or doubleblinded, many had a heterogeneous set of disease criteria, and patient numbers were usually small.

One trial by Bell et al (35) showed an eradication rate of $31.3 \%$, but only 16 patients were studied, and the design was not comparable to the study by Unge et al (36), in which the eradication rate was $54 \%$. Patients in the study by Bell et al included those who were

\section{REFERENCES}

1. Osler W. Diseases of the stomach. In:

The Principles and Practice of

Medicine, 6th edn. New York:

Appleton, 1905:456-7.

2. Hunt RH. Spontaneous

hypochlorhydria. In: Rathbone B], Heatley RV, eds. Campylobacter pylori and Gastroduodenal Disease, 2 nd edn. Oxford: Blackwell Scientific, 1992:176-83.

3. Morris A, Nicholson G. Campylobacter pyloridis causes gastritis and raised fasting gastric $\mathrm{pH}$. Am J Gastroenterol 1987;82:192-9.

4. Defize J, Goldie J, Hunt RH. Effect of Campylobacter pylori on acid production by isolated guinea pig cells. Gut 1988;29:A1435.

5. Cave DR, Vargas M. Effect of a Campylobacter pylori protein on acid metronidazole resistant, and the doses and administration of omeprazole and amoxycillin were different. Bell gave omeprazole, $20 \mathrm{mg}$ once daily in the evening, which provides a shorter duration of $\mathrm{pH}$ greater than 3 than when omeprazole is administered in the morning (37), whereas Unge et al administered omeprazole, $40 \mathrm{mg}$ once daily in the morning. Patients in the study by Bell et al also received amoxycillin, $750 \mathrm{mg}$ daily, which is in contrast to the study by Unge et al, who, in addition to omeprazole, gave amoxycillin, $750 \mathrm{mg}$ twice daily.

The study reported by Unge et al is much larger than that by Bell et al, and is probably more representative of the population, with respect to metronidazole resistance. Unge et al used doses that are more appropriate to the known pharmacodynamics and postulated mechanisms of action (see above). However, Unge et al gave omeprazole alone for two weeks before introducing the amoxycillin; a recent study has suggested that this approach might be a disadvantage to the combination of omeprazole and amoxycillin, which might provide better results if given together initially (38).

A recent study by Bayerdörffer et al (39) compared omeprazole, $40 \mathrm{mg}$ twice daily for 10 days, followed by omeprazole, $20 \mathrm{mg}$ daily for the rest of the six-week period, with omeprazole, $40 \mathrm{mg}$ twice daily, plus amoxycillin, $1 \mathrm{~g}$ twice daily, for 10 days, followed by

secretion by parietal cells. Lancet 1989:ii:187-9.

6. Uehara A, Okumara T, Sekiya C, Okamura K, Takasugi Y, Namiki M.

Interleukin-1 inhibits the secretion of gastric acid in rats: Possible involvement of prostaglandins. Biochem Biophys Res Commun 1989;162:1578-84.

7. Robert A, Olafsson AS, Lancaster C, Zhang W. Interleukin-1 is cytoprotective, antisecretory, stimulates PGE2 synthesis by the stomach and retards gastric emptying. Life Sci 1991;48:123-4.

8. Rademaker JW, Hunt RH. H pylori and gastric acid secretion: the ulcer link? Scand J Gastroenterol 1992;26(Suppl 187):71-7.

9. Mullin GE, Kalloo AN. Does Helicobacter pylori infection affect omeprazole, $20 \mathrm{mg}$ daily, for the rest of the six-week period. H pylori was eradicated in $82 \%$ of the patients in the omeprazole/amoxycillin group. Labenz et al (38) reported that omeprazole, 20 mg twice daily, and amoxycillin, 500 mg four times daily, for two weeks eradicated $\mathrm{H}$ pylori in $82.8 \%$ of 62 patients. However, such treatment for one week proved much less effective (40).

Logan et al (41) gave omeprazole, $40 \mathrm{mg}$ once daily in the morning, and amoxycillin, $500 \mathrm{mg}$ four times daily, for two weeks to 19 metronidazole-resistant $H$ pylori patients, and an eradication rate of $74 \%$ was achieved.

Recent work suggests there is a synergistic effect between omeprazole and triple therapy. In a trial involving 155 duodenal ulcer patients randomly allocated to receive either omeprazole plus hismuth, tetracyline and metronidazole for one week, followed by omeprazole for a further three weeks, or omeprazole alone for four weeks, eradication of $\mathrm{H}$ pylori occurred in $95 \%$ of patients who received omeprazole plus triple therapy but in only $4 \%$ of those taking omeprazole alone (42).

These trials demonstrate a high rate of eradication of H pylori when omeprazole is combined with amoxycillin. Regimens with twice-daily dosing of omeprazole appear to be superior, but the optimal dose, frequency of dosing, and formulation of both drugs remain to be established.

gastric acid secretion?

Gastroenterology 1990;98:A92.

10. Levis, Beardshall K, Haddad G,

Playford R, Ghosh P, Calam J.

Campylobacter pylori and duodenal

uleers: The gastrin link. Lancet

1989;1:1167-8.

11. Wagner S, Gebel M, Bar W, Sculler A, Schmidt FW. The significance of Campylobacter pylori infection on 24 hour intragastric acidity in patients with gastrit is and duodenal ulcer disease. Gastronterology 1990;98:A145.

12. Walsh JH, Richardson CH, Fortran JS. $\mathrm{pH}$ dependence of acid secretion and gastrin release in normal and ulcer subjects. J Clin Invest 1975;55:462-8.

13. Graham DY, Opekim A, Lew GM. Ablation of exaggerated meal-stimulated gastrin release in 
duodenal ulcer patients after clearance of Helicobacter (Campylobacter) pyloni infection. Am J Gastroenterol 1990;85:394-8.

14. Graham DY, Opekum A, Lew GM. Helicobacter pulori-associated exaggerated gastrin release in duodenal ulcer patients. The effect of bombesin infusion and urea infusion. Gastroenterology 1991;100:1571-5.

15. Karnes WE, Ohning GW, Sytnik B. Preservation of $\mathrm{pH}$ inhibition of gastrin release in subjects with Helicobacter pylori. Rev Infect Dis 1991;13:S665-70.

16. McColl KE, Fullarton GM, Chittajalu $R$, et al. Plasma gastrin, daytime intragastric $\mathrm{pH}$, and nocturnal acid output before and at 1 and 7 months after eradication of Helicobacter pylori in duodenal ulcer subjects. Scand ] Gastroenterol 1991:226:339-46.

17. Rangachari PK. Helicobacter pylori and hypergastrinaemia: The quisling option. Scand J Gastroenterol 1991;26(Suppl 187):85-90.

18. Calam J, Levi S, Beardshall K, et al. Helicobacter pylori and duodenal ulcer the gastrin link. In: Malfertheiner $\mathrm{P}$, Ditschuneit H, eds. Helicobacter pylori, Gastritis and Peptic Ulcer. Berlin: Springer Verlag, 1990:317-26.

19. Chittajailu RS, Neithercut WD, Ardill JES, McColl KEL. Helicobacter pylori related hypergastrinaemia is not due to elevated antral surface $\mathrm{pH}$. Scand J Gastroenterol 1992;27:218-22.

20. Teichmann RK, Andress HJ, Gycha S. Immunologic mediated gastrin release. Gastroenterology 1983;84:1333.

21. Kramling HJ, Enders G, Teichmann RK. Antigen induced gastrin release: An immunologic mechanism of gastric antral mucosa. Adv Exp Med Biol 1987;216A:427-9.

22. McColl KEL, Dorrian C, El-Nujumi A. Eradication of Helicobacter pylori reduces hypergastrinaemia due to proton pump inhibitor therapy. Gut 1991:32:A 564 .

23. Calam J, Goodlad RA, Lee CY, et al. Achlorhydria-induced hypergastrinaemia: The role of bacteria. Clin Sci 1991;80:281-4.
24. Samloff IM, Liebman WM, Panitch NM. Serum group 1 pepsinogen by radioimmunoassay in control subjects and patients with peptic ulcer. Gastroenterology 1975;30:912-6.

25. Samloff IM, Varis K, Ihamaki T, Siurala M, Rotter JI. Relationship among serum pepsinogen I and II, and gastric mucosal histology. Gastroenterology 1982;83:204-9.

26. Unge P, Gad A, Gnarpe H. Does omeprazole improve antimicrobial therapy directed towards gastric Campylobacter pylori in patients with antral gastritis? Scand J Gastroenterol 1989;24(Suppl 167):49-54.

27. Iwahi T, Satoh H, Nakao M. Lansoprazole, a novel benzimidazole proton pump inhibitor, and its related compounds have selective activity against Helicobacter pylori. Antimicrob Agents Chemother 1991;35:490-6.

28. Mainguet P, Delmee M, Debongnie JP. Omeprazole, Campylobacter pylori, and duodenal ulcer. Lancet 1989;ii:389-90.

29. Burget DW, Chiverton SC, Hunt RH. Is there an optimal degree of acid suppression for healing of duodenal ulcers? Gastroenterology 1990;99:345-51.

30. Rauws EAJ, Langenberg W, Houthoft HJ, Zanen HC, Tytgat GNJ. Campylobacter pyloridis-associated chronic active antral gastritis. A prospective study of its prevalence and the effects of antibacterial and antiulcer treatment. Gastroenterology 1988:94:33-40.

31. Bayerdörffer E, Ottenjann R. The role of antibiotics in Campylobacter pylori associated peptic ulcer disease. Scand J Gastroenterol 1988:23(Suppl 142):93-100.

32. Chiba N, Rao BV, Rademaker JW, Hunt RH. Meta-analysis of the efficacy of antibiotic therapy in eradicating Helicobacter pylori. Am J Gastroenterol 1992:87:1716-27.

33. Lamouliatte $H$, Vincon G, Quentin-Nourry C, et al. Pharmacokinetics of oral and intravenous amoxycillin in human gastric mucosa. Gastroenterology 1992;102:A107.

34. Van Zanten SJO, Goldie J. Hollingsworth J, Siletti C, Richardson H, Hunt RH. Secretion of intravenously administered antibiotics in gastric juice: Implications for management of Helicobacter pylori. I Clin Pathol 1992:45:225-7.

35. Bell GD, Powell K, Weil J, et al. Experience with omeprazole in combination with either amoxycillin or colloidal bismuth subcitrate in patients with metronidazole-resistant Helicobacter pylori. Eur ] Gastroenterol Hepatol 1991;3:923-6.

36. Unge P, Eriksson K, Bergman B, et al. Omeprazole and amoxicillin in patients with duodenal ulcer: Effect on Helicobacter pvlori eradication and ulcer relapse during a 6-month follow-up. Gastroenterology 1992;102:A183.

37. Chiverton SG, Howden CW, Burget DW, Hunt RH. Omeprazole (20 mg) daily given in the morning or evening A comparison of effects on gastric acidity, and plasma gastrin and omeprazole concentration. Ailment Pharmacol Ther 1992;6:103-11.

38. Labenz J, Gyenes E, Rühl GH, Börsch G. Efficacy of omeprazole and amoxycillin to eradicate Helicobacter pylori. Am J Gastroenterol 1992:87:1271.

39. Bayerdörffer E, Mannes GA, Sommer A, et al. High dose omeprazole treatment combined with amoxycillin eradicates Helicobacter pylori. Eur J Gastroenterol Hepatol 1992;4:697-702.

40. Labenz J, Gyenes E, Rühl GH, Börsch G. Short term therapy with high dose omeprazole and amoxycillin for eradication of Helicobacter pvlori. Ital ] Gastroenterol 1991;23(Suppl 2):109.

41. Logan RPH, Polson RJ, Baron JH, Misiewicz ]J. Follow-up after anti-Helicobacter pylori treatment. Lancet 1991:337:562-3.

42. Hosking SW, Ling TKW, Yung MY et al. Randomised controlled trial of short term treatment to eradicate Helicobacter pylori in patients with duodenal ulcer. Br Med I 1992;305:502-4. 


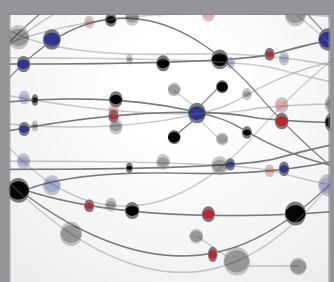

The Scientific World Journal
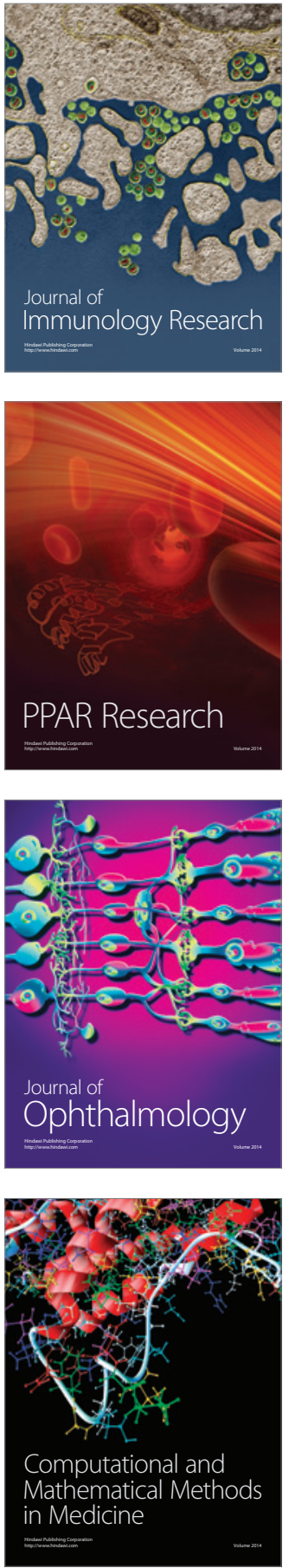

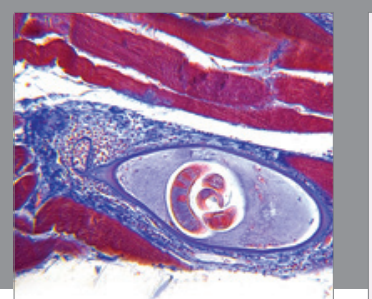

Gastroenterology Research and Practice

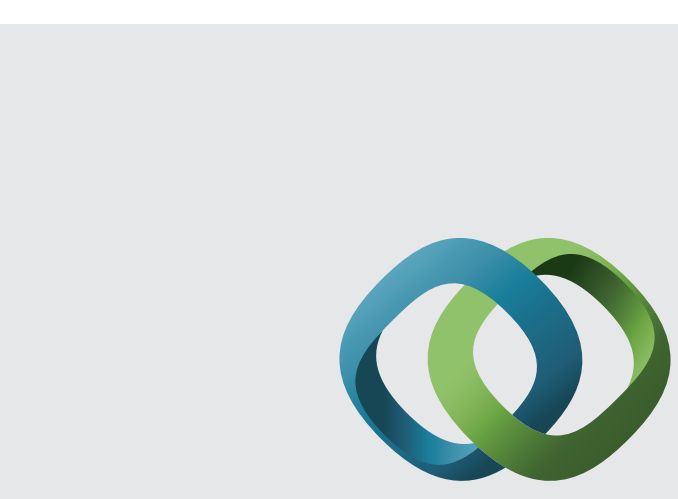

\section{Hindawi}

Submit your manuscripts at

http://www.hindawi.com
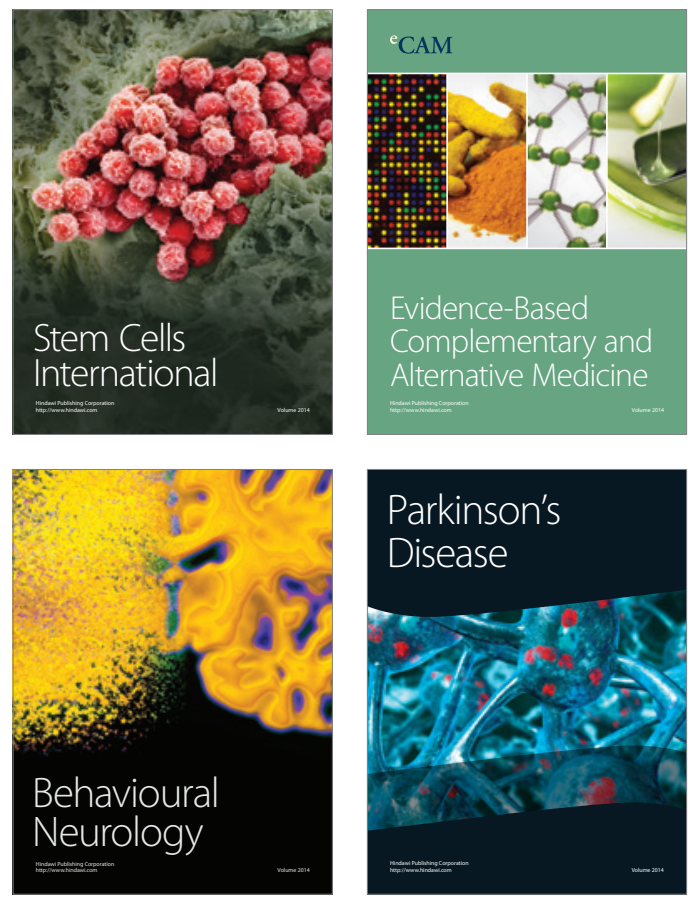
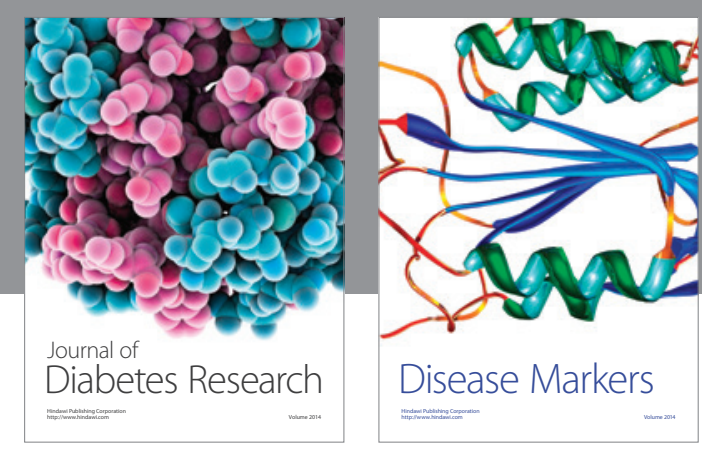

Disease Markers
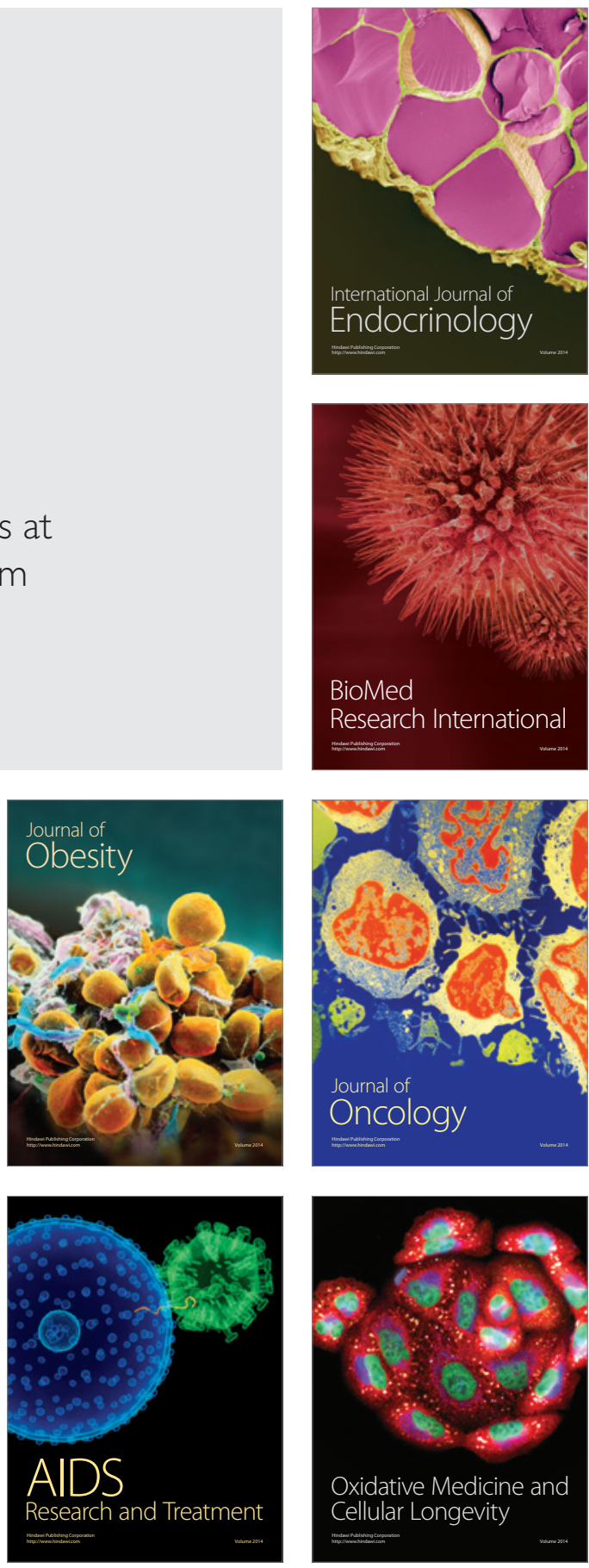